\title{
MERCURY CONTROL WITH THE ADVANCED HYBRID PARTICULATE COLLECTOR
}

Technical Progress Report

For the period October 1 through December 31, 2004

Prepared for:

AAD Document Control

U.S. Department of Energy

National Energy Technology Laboratory

PO Box 10940, MS 921-107

Pittsburgh, PA 15236-0940

DOE NETL Cooperative Agreement DE-FC26-01NT41184; UND Fund 4498

Performance Monitor: William Aljoe

Prepared by:

Stanley J. Miller

Ye Zhuang

Jay C. Almlie

Energy \& Environmental Research Center

University of North Dakota

PO Box 9018

Grand Forks, ND 58202-9018 


\section{EERC DISCLAIMER}

LEGAL NOTICE. This research report was prepared by the Energy \& Environmental Research Center (EERC), an agency of the University of North Dakota, as an account of work sponsored by the U.S. Department of Energy (DOE) National Energy Technology Laboratory. Because of the research nature of the work performed, neither the EERC nor any of its employees makes any warranty, express or implied, or assumes any legal liability or responsibility for the accuracy, completeness, or usefulness of any information, apparatus, product, or process disclosed, or represents that its use would not infringe privately owned rights. Reference herein to any specific commercial product, process, or service by trade name, trademark, manufacturer, or otherwise does not necessarily constitute or imply its endorsement or recommendation by the EERC.

\section{DISCLAIMER}

This report was prepared as an account of work sponsored by an agency of the United States Government. Neither the United States Government, nor any agency thereof, nor any of their employees makes any warranty, express or implied, or assumes any legal liability or responsibility for the accuracy, completeness, or usefulness of any information, apparatus, product, or process disclosed or represents that its use would not infringe privately owned rights. Reference herein to any specific commercial product, process, or service by trade name, trademark, manufacturer, or otherwise does not necessarily constitute or imply its endorsement, recommendation, or favoring by the United States Government or any agency thereof. The views and opinions of authors

expressed herein do not necessarily state or reflect those of the United States Government or any agency thereof.

This report is available to the public from the National Technical Information Service, U.S. Department of Commerce, 5285 Port Royal Road, Springfield, VA 22161; phone orders accepted at (703) $487-4650$.

\section{ACKNOWLEDGMENT}

This report was prepared with the support of the DOE National Energy Technology Laboratory Cooperative Agreement No. DE-FC26-01NT41184. However, any opinions, findings, conclusions, or recommendations expressed herein are those of the author(s) and do not necessarily reflect the views of DOE. 


\title{
MERCURY CONTROL WITH THE ADVANCED HYBRID PARTICULATE COLLECTOR
}

\begin{abstract}
This project was awarded under U.S. Department of Energy (DOE) National Energy Technology Laboratory Program Solicitation DE-FC26-01NT41184 and specifically addresses Technical Topical Area 4 - Testing Novel and Less Mature Control Technologies on Actual Flue Gas at the Pilot Scale. The project team included the Energy \& Environmental Research Center as the main contractor; W.L. Gore \& Associates, Inc., as a technical and financial partner; and the Big Stone Plant operated by Otter Tail Power Company, host for the field-testing portion of the research.
\end{abstract}

Since 1995, DOE has supported development of a new concept in particulate control called the advanced hybrid particulate collector (AHPC). The AHPC has been licensed to W.L. Gore \& Associates, Inc., and is marketed as the Advanced Hybrid ${ }^{\mathrm{TM}}$ filter by Gore. The AHPC combines the best features of electrostatic precipitators (ESPs) and baghouses in a unique configuration, providing major synergism between the two collection methods, both in the particulate collection step and in the transfer of dust to the hopper. The AHPC provides ultrahigh collection efficiency, overcoming the problem of excessive fine-particle emissions with conventional ESPs, and it solves the problem of reentrainment and re-collection of dust in conventional baghouses. The AHPC also appears to have unique advantages for mercury control over baghouses or ESPs as an excellent gas-solid contactor.

The objective of the original five-task project was to demonstrate $90 \%$ total mercury control in the AHPC at a lower cost than current mercury control estimates. The approach included benchscale batch tests, larger-scale pilot testing with real flue gas on a coal-fired combustion system, and field demonstration at the 2.5-MW scale at a utility power plant to prove scale-up and demonstrate longer-term mercury control.

The scope of work was modified to include an additional sixth task, initiated in April 2003. The objective of this task was to evaluate the mercury capture effectiveness of the AHPC when used with elemental mercury oxidation additives.

This project, which is now in the final report phase, demonstrated at the pilot-scale level a technology that provides a cost-effective technique to control mercury and, at the same time, greatly enhances fine particulate collection efficiency. The technology can be used to retrofit systems currently employing inefficient ESP technology as well as for new construction, thereby providing a solution for improved fine particulate control combined with effective mercury control for a large segment of the U.S. utility industry as well as other industries. 


\section{SUMMARY AND STATUS}

Experimental results for the project have been reported in the previous quarterly technical reports. The only remaining planned activity is completion of the final technical report. Since the only activity during the October-December 2004 period is work on the final technical report for the project, no experimental results are presented in this report. The project end date has been extended to March 31, 2005, to allow sufficient time for completing the final technical report. 